\title{
NON-THERMAL INFLUENCE OF THE mm-RANGE ELECTROMAGNETIC RADIATION ON THE PEROXIDE OXIDATION OF EGG YOLK LIPOPROTEINS
}

\author{
L. A. Bulavin, N. M. Zabolotna \\ Taras Shevchenko Kyiv University, Physics Faculty, \\ 12 Hlushkova Pr., Kyiv, 03022, Ukraine
}

(Received July 30, 1998; received in final form November 11, 1999)

\begin{abstract}
The effect of weak electromagnetic radiation in the millimetre range upon the chemiluminescence intensity accompanying the process of peroxide oxidization of lipoproteins was studied. It is shown that in the temperature range of $35 \div 43^{\circ} \mathrm{C}$ the intensity is independent of the temperature up to the experimental errors. It is though strongly dependent on the composition of the buffer solution and radiation frequency. The results are explained using a modified Onsager model.
\end{abstract}

Key words: chemiluminescence, lipoprotein, Onsager model, resonance, tunnelling.

PACS number(s): 87.15.-v, 78.60.Ps, 78.60.Ya

\section{INTRODUCTION}

Studies of the influence of low intensity $\left(<10 \mathrm{~mW} / \mathrm{cm}^{2}\right)$ high frequency $\left(10^{10}-10^{11}\right) \mathrm{Hz}$ electromagnetic waves (EMW) on the biological systems have been the subject of special interest for about 20 years due to the diversity of the reported effects and perspectives of application in biology and medicine. Currently it is one of the most popular and interesting fields of biophysics. Among the discovered effects of the millimetre waves are influence on the growth of microorganismes, their susceptibility to pharmacological preparations, interaction of cells with viruses, changes in the rheological properties of biological solutions [1], weakening of the effect of radiation and chemical factors on the marrow blood formation in animals, etc. The set of these phenomena which depend on the spectra of the electromagnetic waves is called generally EHF (extremely high frequency)-bioeffect. Further investigations showed even more subtlenature of this influence: e.g. "memory" of organism of being exposed to irradiation, frequency and amplitude modulation effects, various cooperative effects of EMW together with other factors, etc.

First reports on the curative effects of EHF EMW appeared in the late 1980s and quickly found their way into medical application. The effect of the resonance action of localized low-intensity millimetre EMW upon an organism was discovered at Kyiv Shevchenko University. It was shown that the correction of pathological functional states of human organism can be achieved by exposing special points of it to EHF EMW in certain regimes (with the frequency individual for each person).

All the above phenomena can be interpreted as the manifestation of anomalous susceptibility of biological systems to millimetre radiation.

A wide set of experimental data on EHF-bioeffect attracted the theorists' interest to its physical mechanisms. None of the plethora of the existing theories is capable of explaining the observed effects. In this work a modification of Onsager model is used to describe reasonably well the observations of the authors.

\section{NON-THERMAL EFFECT OF ACOUSTIC AND ELECTROMAGNETIC WAVES ON BIOLOGICAL OBJECTS}

A wide introduction of physical methods allows to study biological phenomena on the molecular level. A starting point of such an approach is the concept of life as a manifestation of physical and chemical processes taking place in complex molecular systems, which interact with other systems by interchange of energy and matter [2]. A peculiarity of the living organisms distinguishing them from non-alive objects lies in a special organization of complex molecular systems governed by the same laws as non-alive objects.

Building proteins from aminoacids requires energy while their decomposition in cell aquatic environment can take place spontaneously and leads to energy formation. An organism therefore has to regenerate proteins continuously to replenish for this decay. So, all proteins and in general all living organisms are in a metastable state $[2,3]$.

Life is possible due to a very long transition time between this unstable state and a stable state of thermodynamic equilibrium. Currently one of the most important problems is to find a description of the structure, properties and functions of the simplest biological systems [2, 4]. The approach suggested lies in distinguishing those from the knowledge of the composition of the basic biological units and taking into account the processes inside molecules and between them, and conformational changes in macromolecules caused by them, energy, electron and proton transfer within molecules as well as between them.

All the biological molecules and super molecular structures work in aquatic environment. Interactions with it often play an important role. Considering chemical transformations of molecules and other biological structures we should remember about the presence of water as a solvent.

The influence of external factors on water has long been extensively studied $[1,5$ and references therein]. The 
water in nature is never pure - it always contains admixtures of gases, ions of dissolved salts, etc. Under certain circumstances the presence of admixtures affects the properties of the solvent (water) [1], so the properties of aquatic systems depend on external conditions: temperature, pressure, exposure to electromagnetic and acoustic waves, etc. The changes in external fields modify water properties, thus affecting the processes in the aquatic environment.

Physical mechanisms of effects of exposure of aquatic environment to acoustic waves were studied in $[6,7]$. There is thermal and non-thermal aspects to these effects. Biological effects of exposure to acoustic waves were reported. The exact mechanism remains unclear. One of the reasons for that is a large number of physical processes initiated by the acoustic waves.

Non-thermal effects of weak EWM on aquatic systems and biological objects is understood much better [8-10]. This is mainly due to its medical and biological implications. Two properties of the biological influence of EMW were discovered [10]:

- Very low level of the intensity of radiation causing a biological reaction of the organism. Well reproducible effects are observed below the level of the thermal noise at physiological temperatures.

- Narrow resonance nature of the interaction. This effect is present only at certain individual frequencies and disappears for frequencies different by 0.01 percent.

A physical reason for the existing of such resonances is unclear, though there are ideas $[11,12,13]$ about the important role of phase transitions, which is consistent with synergetic description of dissipative structures [13-15].

It should be mentioned that even the simplest living bioobjects are too complex to be studied by traditional physical methods. Therefore it is common [10, $16,17]$ to work with model systems instead, such as, e.g. blood serum and its derivatives, water solutions of biomolecules, "sub-alive systems" [10] — water rich in active microadmixtures, etc. In these cases optical and rheological properties of the objects are studied.

An example of the reaction important for life is peroxide oxidation of the egg yolk lipoproteins [18] which is studied by observing the chemiluminescence of the reaction. luminescent substance is luminol, which emits light under oxidation in the reaction with $\mathrm{HO}^{\bullet}$ and $\mathrm{O}_{2}^{\bullet-}$. So, the chemiluminescence rate is dependent on two radicals.

\section{A METHOD OF BIOCHEMILUMINESCENCE}

Luminescence is light emission excited by the energy of any kind except thermal, and not described by thermal radiation laws. Depending on the source of the energy luminescent substances are classified into chemiluminophors, electroluminophors and photoluminophors. Boichemiluminescence is a kind of chemiluminescence, special to living organisms.

\section{A. Active oxygen forms}

Because chemiluminescence is a process which requires sufficient energy to be stored in the reaction products, in order to excite their electron levels, such reactions often have oxygen and free radicals as reagents. That is one of the reasons for the efficiency of the biochemiluminescence method when studying free radical processes in living systems. Free radical is a molecule or its part which has an unpaired electron. Unpaired electron is a free valence, so free radicals are easily involved in chemical reactions and often start a chain reaction. The most important for living systems free radicals are radicals of oxygen, and unsaturated fat acids in lipids and phenol derivatives.

In biological systems free radicals are produced in one electron oxidization of organic molecules or in one electron reduction of oxygen. Radicals produced in reduction of molecular oxygen, hydrogen peroxide and singlet oxygen are sometimes called "active oxygen forms":

- ${ }^{1} \mathrm{O}_{2}$ - singlet oxygen,

- ${ }^{-} \mathrm{O}-\mathrm{O}^{\bullet}$ - superoxide anion radical $\left(\mathrm{O}_{2}^{\bullet-}\right)$,

- $\mathrm{HO}-\mathrm{O}^{\bullet}$ - hydrogen peroxide radical,

- $\mathrm{OH}^{\bullet}$ — hydroxyl radical,

- $\mathrm{H}_{2} \mathrm{O}_{2}$ - hydrogen peroxide.

These active oxygen forms are the first to appear in the cell metabolism reaction chain, while the rest of the radicals leading to chemiluminescence are most probably a result of the active oxygen forms reactions with organic molecules, first of all unsaturated fat acid residuals of membrane phospholipids and lipoproteins.

The first stage of one-electron reduction of oxygen is the formation of $\mathrm{O}_{2}^{:-}$. It forms in all aerobe cells and is the "ancestor" of active oxygen forms and is a weak reducent (the potential of the reaction $\mathrm{O}_{2}+e^{-} \leftrightarrow \mathrm{O}_{2}^{\bullet-}$ is $-0.33 \mathrm{~V}$ ). The formation of $\mathrm{O}_{2}^{\bullet-}$ in biological systems is accompanied by the $\mathrm{H}_{2} \mathrm{O}_{2}$ formation as a result of the dismutation of superoxide radicals which can be spontaneous or catalyzed by superoxidedismutase (SOD):

$$
2 \mathrm{O}_{2}^{\bullet-}+2 \mathrm{H}^{+} \stackrel{\text { SOD }}{\longrightarrow} \mathrm{H}_{2} \mathrm{O}_{2}+\mathrm{O}_{2}
$$

$\mathrm{H}_{2} \mathrm{O}_{2}$ is a weak oxidant manifesting this property in the presence of metals with changing valency. Highly reactive $\mathrm{HO}^{\bullet}$ is formed in the reaction. It is a very important active oxygen form from the biological viewpoint as it damages nuclein acids causing mutagen and lethal influence; as well as activates ferments, initiates reactions of peroxide oxidation of lipids. But its lifetime is very short (about $100 \mathrm{~ns}$ ) due to high activity, so its adverse effect depends on the formation site.

Another active agent reacting with organic molecules is the singlet oxygen ${ }^{1} \mathrm{O}_{2}$. The base triplet state of ${ }^{1} \mathrm{O}_{2}$ 
has lower free energy than singlet ${ }^{1} \mathrm{O}_{2}$ states. The formation of this active oxygen form plays a very important role in reactions of photooxidation of biological substances. Another channel of the ${ }^{1} \mathrm{O}_{2}$ formation is nonphotochemical reactions of $\mathrm{O}_{2}$ dismutation and reactions of some strong oxidants.

The formation of the active oxygen forms and the following free radical reactions are the basis of cell chemiluminescence.

\section{B. Activated chemiluminescence}

If chemiluminescence is enhanced using some substances it is called activated. Activators are subdivided into physical ones and the chemiluminescent sound. The latter are substances which emit light in the course of chemical reactions with the object. The most widely used chemiluminescent sounds are luminol and lucigene, the chemical formulas for them are presented in Fig. 1.
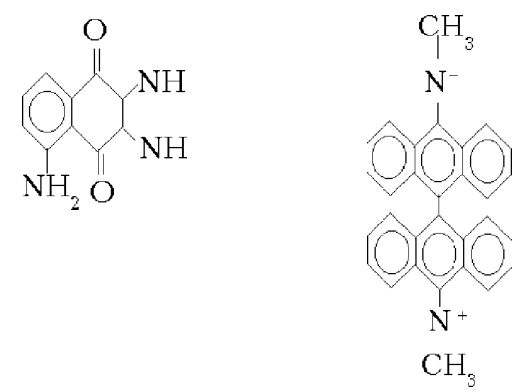

Fig. 1. Chemical formula of luminol and lucigene.

In this work luminol was used. The luminescence reaction requires its oxidation by $\mathrm{HO}$ or $\mathrm{O}_{2}$, depending thus on the concentration of the two free radicals.

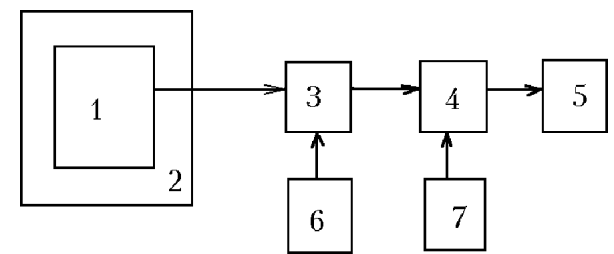

Fig. 2. Schematic of the spectrometer KShDA; 1 - dark chamber, 2 - thermostat, 3 - electron photomultiplier, 4 amplifier, 5 - recorder, 6 and 7 - power supply.

\section{DESCRIPTION OF THE EXPERIMENTAL SETUP}

The experiments were carried out on modified spectrophotometer KShDA-01 which has the following technical parameters:

- sensitivity of $10^{4}$ quanta/sec,
- spectral range $300-600 \mathrm{~nm}$,

- working sample volume - not more than $8 \mathrm{ml}$,

- electronic temperature control $35 \div 38^{\circ} \mathrm{C}$,

- sample mixing — 600, 900, 1200 and $1500 \mathrm{rpm}$.

Schematic of the setup is shown in Fig. 2, where 1 dark chamber, 2 - thermostat, 3 - electron photomultiplier, 4 - amplifier, 5 - recorder, 6 and 7 - power supplies.

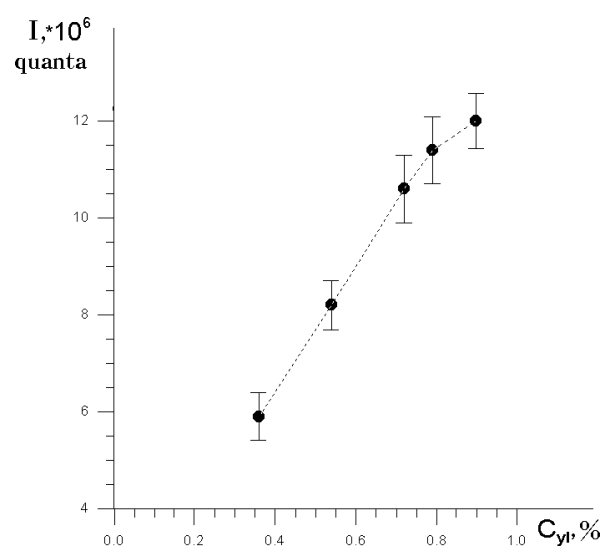

Fig. 3. Dependence of total intensity of chemiluminescence $I_{\text {tot }}$ on the yolk lipoproteins concentration $C_{\mathrm{yl}}(\%, \mathrm{w} / \mathrm{v})$. Peroxide concentration $C_{\mathrm{ox}}=0.43 \%$, temperature $t=37^{\circ} \mathrm{C}$.

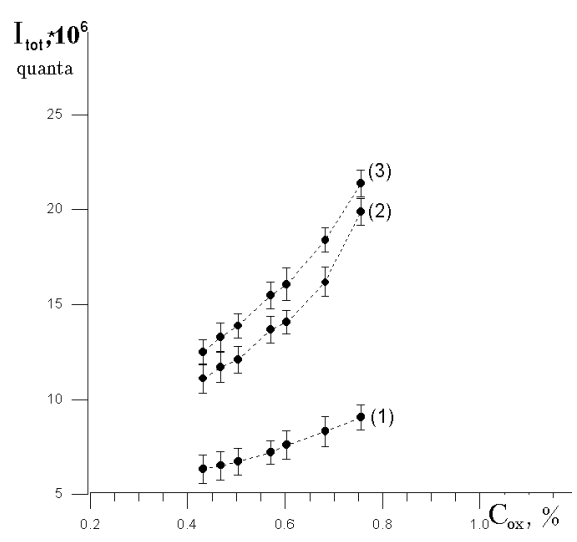

Fig. 4. Dependence of total intensity of chemiluminescence on $I_{\text {tot }}$ the peroxide concentration $C_{\text {ox }}$. Curves (1), (2) and (3) correspond to yolk concentrations $C_{\mathrm{yl}}=0.36,0.72$ and $0.79 \%(\mathrm{w} / \mathrm{v})$. 


\section{EXPERIMENTAL RESULTS}

The following results were obtained [19]:

- The dependence of integral intensity of luminescence on the concentration of $\mathrm{H}_{2} \mathrm{O}_{2}\left(C_{\mathrm{ox}}\right)$ and yolk lipoproteins $\left(C_{\mathrm{yl}}\right)$ was studied at the constant temperature of $t=37^{\circ} \mathrm{C}$ and the volume of $V=1.09 \mathrm{ml}$. After a quick injection of $0.2 \mathrm{ml}$ of hydrogen peroxide chemiluminescence intensity rises gradually to the maximum and later reduces slowly. Integral luminescence intensity is plotted versus the concentration of lipoproteins in Fig. 3 and $\mathrm{H}_{2} \mathrm{O}_{2}$ in Fig. 4.

- The experiments at $35,37,41$ and $43^{\circ} \mathrm{C}$ showed the total chemiluminescence intensity to be nearly independent of the temperature. chemiluminescence intensity is plotted versus temperature in Fig. 5.

- Total chemiluminescence intensity is plotted versus the frequency of the EMW in Fig. 6. Besides this, the effect of the exposure of the sample to EHF EMW on the kinetics of the reaction was found, though it was not studied in detail.

- chemiluminescence growth time depends significantly on the sample's temperature and buffer solution type. In our case this growth time was of the order of several seconds.

\section{MODEL}

\section{A. Propositions of Onsager model}

Onsager model was suggested originally for the description of the conductivity of weak electrolytes. The assumptions of the model are as follows [20, 21]:

- Concentration of the ions is such that interaction of the like ions can be neglected.

- Interaction of the different kind of ions is pairwise.

- Interacting ion pairs are in thermal equilibrium with the environment.

- Ion motion is of diffusive nature.

- The process takes place in isotropic medium.

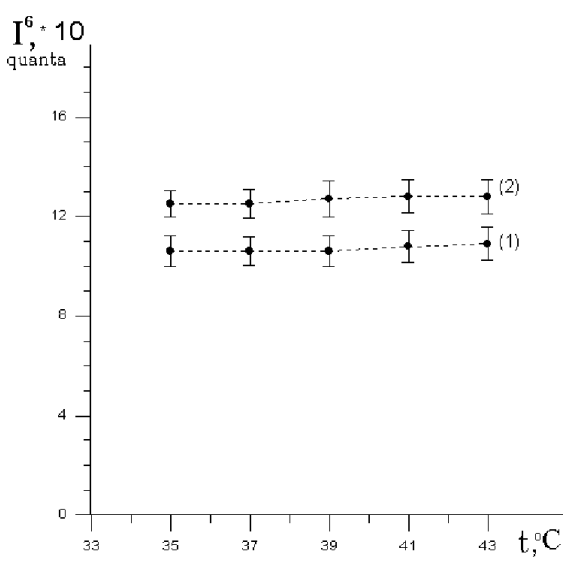

Fig. 5. Temperature dependence of total intensity of chemiluminescence $I_{\text {tot }}$. Curves (1), (2) correspond to yolk lipoproteins' concentrations $C_{\mathrm{yl}}=0.72$ and $0.79 \%(\mathrm{w} / \mathrm{v})$. Peroxide concentration $C_{\mathrm{ox}}=0.43 \%$.

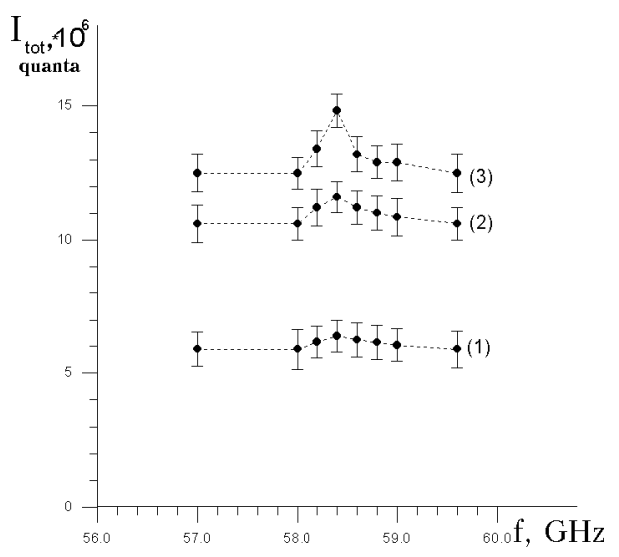

Fig. 6. Dependence of total intensity of chemiluminescence $I_{\text {tot }}$ on the external field frequency $f$. Curves (1), (2) and (3) correspond to yolk lipoproteins' concentrations $C_{\mathrm{yl}}=0.36$, 0.72 and $0.79 \%(\mathrm{w} / \mathrm{v})$. Peroxide concentration $C_{\mathrm{yl}}=0.43 \%$, $t=37^{\circ} \mathrm{C}$, influence time $\tau=300 \mathrm{~s}$.

Later Onsager model was used to describe the process of photogeneration of electric charges or luminescence in the ordered media [22, 23].

The initial equation of the model in that case was the continuity equation for the distribution function of the corresponding substances:

$$
\frac{\partial W(r, t)}{\partial t}=-\operatorname{div} \mathbf{J}
$$

where $J$ is the diffusion flux and $W(r, t)$ is the probability density. The boundary conditions were:

$$
\begin{aligned}
& \left.W(r, t)\right|_{r=0}=0, \\
& \left.W(r, t)\right|_{r=\infty}=0,
\end{aligned}
$$


which corresponds to two sinks of particles - one at the location of the ion of the opposite sign (in recombination) and the other at infinity.

\section{B. Modification of the Onsager model}

The experiments showed that the growth time of the chemiluminescence depends significantly on the temperature of the sample. The dependence of $\ln \left(t\left(\frac{1}{T}\right)\right)$ indicates the activation nature of the oxidation processes. The value of $t$ depends significantly on temperature, concentration of hydrogen peroxide and buffer solution composition, and was of order of several seconds. Changing viscosity of the buffer solution (by adding glycerine) leads to an increase in the luminescence growth time $t$ and in the case of $100 \%$ glycerine instead of phosphate buffer luminescence flare is not observed at all. These properties lead to the conclusion that the process of the peroxide oxidation of the yolk lipoproteins is diffusion controlled reaction.

Let us consider the conditions under which the process takes place. The temperature is kept constant and there is no mixing. We assume the particles (oxygen and luminescence centres) to have spherical symmetry, their concentration to be low and that there is no interaction between the like particles. The motion of the molecules was assumed to be Brownian. These are the assumptions of the standard Onsager model [22-24] which was suggested to describe the conductivity of weak electrolytes.

For uncharged particles (a large growth time of chemiluminescence indicates that the particles are uncharged) and assuming diffusive nature of fluxes one has:

$$
\mathbf{J}=-D \operatorname{grad} W
$$

From the continuity equation:

$$
\frac{\partial W(r, t)}{\partial t}=-\operatorname{div} \mathbf{J}=\frac{D}{r^{2}} \frac{\partial}{\partial r}\left(r^{2} \frac{\partial W}{\partial r}\right)
$$

The following boundary conditions are applied:

$$
\begin{aligned}
& h \cdot W(R, t)=\left.D \frac{\partial W}{\partial r}\right|_{r=R}, \\
& H \cdot W(L, t)=-\left.D \frac{\partial W}{\partial r}\right|_{r=L} .
\end{aligned}
$$

Conditions (6) and (7) where $R$ and $L$ are the boundaries of some volume element $d V, h$ and $H$ are parameters which determine the probabilities of the oxygen approaching a luminescence centre and exiting its vicinity correspond to a partial (diffusive) penetration of the particles at boundaries [25]. It is common to use the boundary conditions $W(R, t)=0$ or $W(L, t)=0$ which corresponds to a full particle absorption at the boundaries.

The initial conditions are:

$$
\left.W(r, t)\right|_{t=0}=W_{0}
$$

where $W_{0}$ is the value of $W$ at $t=0$.

Let us consider a stationary case of the problem (5)(8). Integrating $(5)-(7)$ in time, taking into account that $W(r, \infty)=0$ because all the particles either leave the volume $d V$ or disappear in the luminescence act one obtains:

$$
\begin{aligned}
-W_{0} & =\frac{D}{r^{2}} \frac{\partial}{\partial r}\left(r^{2} \frac{\partial \bar{W}}{\partial r}\right), \\
h \cdot \bar{W}(R) & =\left.D \cdot \frac{\partial \bar{W}}{\partial r}\right|_{r=R}, \\
H \cdot \bar{W}(L) & =-\left.D \cdot \frac{\partial \bar{W}}{\partial r}\right|_{r=L},
\end{aligned}
$$

where $\bar{W}(r)=\int_{0}^{\infty} d t W(r, t)$. The solution of system (9)(11) is

$$
\begin{aligned}
& \bar{W}(R) \\
& =\frac{W_{0}}{3} \cdot \frac{\left(L^{3}-R^{3}\right) / L^{2} h+1 / 2 D\left(L^{2}+R^{3} / L-3 R^{2}\right)}{1+R h / D-R^{2} h / D L+R^{2} h / L^{2} H} .
\end{aligned}
$$

The probability of interaction of an oxygen atom and lipoprotein molecule initially separated by a distance of $R_{0}$ is:

$$
I=h 4 \pi R^{2} \bar{W}(R)
$$

After substitution one gets:

$$
I=\frac{4 \pi R^{2} W_{0} h}{3} \frac{L / H+L^{2} h / 2 D}{1+R h / D+R^{2} h / L^{2} H}
$$

The parameters of $H$ and $h$ are determined by the tunnel processes only.

Equations (13) and (14) are a generalization of the results of [24].

\section{DISCUSSION OF THE RESULTS}

As a result of the analysis of the modified Onsager model we established that the possibility of the interaction between the oxygen atom and the lipoprotein molecule is determined by equations (14), (19), (21).

We have to notice that since the atomic oxygen is derived from the peroxide $\mathrm{H}_{2} \mathrm{O}_{2}$ inserted into our solution,

$$
W_{0}=k C_{\mathrm{ox}}
$$

where $k$ is the dissociation constant of the $\mathrm{H}_{2} \mathrm{O}_{2}$ molecule. 
Measuring experimentally the luminescence intensity $I_{\text {tot }}$ depends on the radiation of all the luminescence centres in the volume $V$. So,

$$
\begin{aligned}
I_{\mathrm{tot}} & =I v C_{\mathrm{yl}} \\
& =\frac{4 \pi R^{2} h k C_{\mathrm{ox}} C_{\mathrm{yl}} V}{3} \frac{L / H+L^{2} h / 2 D}{1+R h / D+R^{2} h / L^{2} H} .
\end{aligned}
$$

As was determined, $D / h^{2}$ exponentially decreases with the increase of the temperature [19] which allows us to assume that the dependence of $h$ on the temperature is weak since for the diffusion coefficient the dependence is

$$
D \propto \exp \left(-U_{a} / k_{B} T\right)
$$

where $U_{a}$ is the diffusion activation energy, $k_{B}$ is Boltzman constant.

Remembering that $H$ describes the conditions of oxygen atom leaving the liquid volume under consideration it is clear that it depends on the structure of the liquid. Assuming that no phase transitions occurred in the liquid (the experiments showing no thermal capacity jumps), we conclude that the dependence of $H$ on the temperature also must be weak. Thus we conclude that the weak $I_{\text {tot }}$ dependence on the temperature could occur in two cases. The first one is realized if the condition

$$
L / H \gg L^{2} h / 2 D ; \quad 1+R^{2} h / l^{2} H \gg R h / D
$$

is satisfied. Then

$$
I_{\text {tot }} \propto C_{\mathrm{ox}} C_{\mathrm{yl}} h \frac{L / h}{1+R^{2} h / L^{2} 2 H} .
$$

We have the second case if

$$
L^{2} h / 2 D \gg L / H ; \quad R h / D \gg 1+R^{2} h / l^{2} H .
$$

In this case

$$
I_{\text {tot }} \propto C_{\text {ox }} C_{\mathrm{yl}} h
$$

Equations (19) and (21) follow from the proposed model having in mind the notes made about the $h$ and $H$ temperature dependences. Experimentally measured dependences $I_{\text {tot }}\left(C_{\mathrm{ox}}\right)$ and $I_{\text {tot }}\left(C_{\mathrm{yl}}\right)$ are shown on Fig. 3 and 4 .

The data of Fig. 3 lead one to some conclusions about the parameters of the model. The smallest timescale which determines the rate of the chemiluminescence growth is

$$
\tau=D / h^{2}
$$

Hence the dependence of $I$ on the temperature is also weak. $I$ is plotted versus the temperature in Fig. 3 . Fig. 3 shows the weak $I_{\text {tot }}$ dependence on the temperature which can be a good reason for the approaches made above $(18,20)$. As can be seen, the model agrees with the experiment well.

Linear character of the dependences $I_{\text {tot }}\left(C_{\mathrm{ox}}\right)$ and $I_{\text {tot }}\left(C_{\mathrm{yl}}\right)$ correlates very well with (19) and (21). The dependence of $I_{\text {tot }}$ on the parameters of the external radiation is shown on Fig. 6. The comparison of Fig. 6 with (19) and (21) shows that experimentally measured dependence $I_{\text {tot }}(f)$ is possible for a resonance character of the $H$ and $h$ dependence on the external electromagnetic (EM) radiation. One of the possible reasons of that could be the reported change of the rheological properties of aqueous solutions under the influence of the external EM radiation of the $m m$-range [10].

As can be seen the obtained results are relatively well described by the modified Onsager model while the mechanism of the influence of the electromagnetic waves upon the model biologic system is unclear.

\section{CONCLUSIONS}

The subject of the study was peroxide oxidation of lipids. Processes similar to this are responsible for a transport of the matter across the membranes in normal cells. Anomalies in the mechanism can lead to various pathologies.

Our study has been carried out on the egg yolk lipoproteins using the method of activated chemiluminescence. The experiments show that:

- Irradiation of the sample by electromagnetic waves of frequencies of $56.73 \ldots 76 \mathrm{GHz}$ and intensities of $10^{-7} \ldots 10^{-6} \mathrm{~W} / \mathrm{cm}^{2}$ for 5 min leads to an increase in chemiluminescence intensity of 30 to 50 per cent.

- Probability of single luminescence act during the process is independent of the temperature of the sample.

The results were described using Onsager model based on the assumptions of diffusion controlled nature of the peroxide oxidation process and on existing certain energy barrier controlled by external radiation which determines the probability of the reagents interaction. The model predicts an exponential dependence of the luminescence growth time on the temperature which agrees with the experimental data. 
[1] V. Ja. Antonchenko, A. S. Davydov, V. V. Iljin, Osnovy Fiziki Vody (Basic of Physics of Water) (Naukova Dumka, Kyiv, 1991).

[2] A.S. Davydov, Biologiia a kvantovaia miekhanika (Biology and Quantum Mechanics) (Naukova Dumka, Kyiv, 1975).

[3] A. S. Davydov, Solitony v Moliekuliarnykh Sistiemakh (Solitons in Molecular Systems) (Naukova Dumka, Kyiv, 1998).

[4] H. Frouhlich, Advances in Electronics and Electron Physics 53, 85, 148 (1980).

[5] D. Ebeling, V. Kaugman, Struktura i Svoistva Vody (Structure and Properties of Water) (Hydrometeoizdat, Leningrad, 1975).

[6] Primienieniie Ul'trazvuka v Mieditsinie. Fizichieskiie Osnovy (Application of Ultrasound in Medicine. Physical Principles) (Mir, Moscow, 1989).

[7] S. N. Romanov, Biologicheskoie Dieistviie Miekhanichieskikh Koliebanii (Biological Effect of Mechanical Oscillations) (Nauka, Leningrad, 1983).

[8] V. D. Iskin, Biologicheskiie Effiekty Millimietrovykh Voln (Biological Effects of Millimetre Waves) (Kharkiv State University publishing, Kharkiv, 1990).

[9] Nietieplovyie Effiekty Millimietrovogo Izluchieniia (Nonthermal effects of millimetre waves), edited by N. D. Deviatkov (IRE AN USSR, Moscow, 1981).

[10] S. P. Sitko, L. N. Mkrtchan, Vviedieniie v Kvantovuiu Mieditsinu (Introduction to Quantum Medicine) (Pattern, Kyiv, 1994).

[11] L. A. Bulavin, Krytychni Yavyshcha u Ridynakh (Critical Phenomena in Liquids) (Physics Faculty, Kyiv University, 1997).

[12] I. A. Fakhretdinov, A. V. Chalyj, Physics of the Alive, 4, iss. 1, 32 (1996).

[13] I. V. Nezhynskij, V. M. Sysoev, A. V. Chalyj, preprint ITPh, Kyiv (1993).

[14] L. S. Polak, A. S. Mikhailov, Samoorganizatsiia v Nieravnoviesnykh Fiziko-khimichieskikh Sistiemakh (Selforganization in Nonequilibrium Physicochemical Systems)
(Nauka, Moscow, 1983).

[15] V. Ebeling, Obrazovaniie Struktur pri Nieobratimykh protsessakh (Structure Formation in Irreversible Processes) (Mir, Moscow, 1979).

[16] B. N. Belintsev, Usp. Fiz. Nauk 141, 55 (1983).

[17] G. Haken, Informatsiia i Samoorganizatsiaa. Makroskopichieskii Podkhod k Slozhnym Sistiemam (Information and Selforganization. A Macroscopic Approach to Complex Systems) (Mir, Moscow, 1991).

[18] Yu. A. Vladimirov, A. I. Archakov, Pieriekisnoie Okislieniie Lipidov v Biologichieskikh Miembranakh (Peroxide oxidation of lipids in biological membranes) (Nauka, Moscow, 1972).

[19] L. A. Bulavin, N. M. Zabolotnaya, in Materialy III Vseukrains'koi Naukovoi Konferentsii "Fundamental'na ta Profesiina Pidhotovka Fakhivtsiv z Fizyky", Chastyna II (Proceedings of III Ukrainian Scientific Conference "Fundamental and Professional Training of Specialists in Physics", Part II) (Drahomanov National Pedagogical University, Kyiv, 1998).

[20] A. A. Ovchinnikov, S. F. Timashev, A. A. Belyj, Kinetika Diffuzionno-Kontroliruiemykh Reaktsyi (Kinetics of Diffusion Controlled Chemical Processes) (Chemistry, Moscow, 1986).

[21] K. Kao, V. Huang, Pierienos eliektronov v Tvierdukh Tielakh, Tom 2 (Transfer of Electrons in Solids, Vol. 2) (Mir, Moscow, 1984).

[22] E. A. Silin'sh, M. B. Kurik, V. Chapek, Eliektronnyie Protsessy v Organichieskikh Moliekuliarnykh Kristallakh (Electron Processes in Organic Molecular Crystals. Localization and Polarization) (Zinatne, Riga, 1988).

[23] M. Pope, Ch. Svenberg. Eliektronnyie Protsessy v Organichieskikh Kristallakh, Tom 2 (Electron Processes in Organic Crystals, Vol. 2) (Mir, Moscow, 1985).

[24] Ya. B. Zeldowich, A. D. Myshkis, Eliemienty Matiematichieskoi Fiziki (Elements of Mathematical Physics) (Nauka, Moscow, 1973).

[25] V. I. Arkhipov, A. P. Tyutnev, V. P. Nikitenko, D. N. Sadovnichij, Khim. Fiz. 15, 91 (1996).

\title{
НЕТЕПЛОВИЙ ВПЛИВ ЕЛЕКТРОМАГНЕТНОГО ОПРОМІНЕННЯ МІЛІМЕТРОВОГО ДІЯПАЗОНУ НА ПЕРЕКИСНЕ ОКИСЛЕННЯ ЛІПОПРОТЕЇНІВ ЯЄЧНОГО ЖОВТКА
}

\author{
Л. А. Булавін, Н. М. Заболотна \\ Кийвсъкий уніберситет ім. Т. ІІІебченка, фізичний факультет \\ просп. Глушкова, 6, 0зо22, Киӥ, Украӥна \\ E-mail: bulavin@molphys.ups.kiev.ua,natala@alfven.ups.kiev.ua
}

\begin{abstract}
Вивчено вплив слабкого електромагнетного опромінення в міліметровому діяпазоні на інтенсивність хемілюмінесценції, що супроводжує перекисне окислення ліпопротеїнів. Показано, що в області температур $35 \div 45^{\circ} \mathrm{C}$ інтенсивність не залежить від температури в межах точности експерименту. Хоча вона сильно залежить від складу буферного розчину ӥ частоти опромінення. Результати пояснені за допомогою модифікованої моделі Онзагера.
\end{abstract}

